\title{
Critical Analysis On Institutional Capital On Trade And Environmentally Sustainable Development Under NAFTA
}

\author{
https://doi.org/10.21272/sec.4(2).21-31.2018
}

José G. Vargas-Hernández

M.B.A., PhD, Visiting Scholar at Laurentian University, University Center for Economic and Managerial

Sciences, University of Guadalajara, Mexico

\section{Elsa Patricia Orozco-Quijano}

M.B.A., PhD, Master Lecturer, Faculty of Management, Laurentian University, Mexico

Jorge Virchez

$\mathrm{PhD}$, Full Professor, School of Northern and Community Studies (Geography), Laurentian University, Mexico

\begin{abstract}
This paper summarizes the arguments and counterarguments within the scientific discussion on the issue of institutional capital and its implications on trade and environmentally sustainable development under NAFTA (North America Free Trade Agreement). The main purpose of the research is conducting a critical analysis the implications in terms of the relationship between cooperation, conflict and institutional capital, as well as their interactions with trade-marketing and environmentally sustainable development policy making under the framework of NAFTA. Systematization literary sources and approaches for solving the problem of whether the North American Free Trade Agreement should continue to operate despite the challenges and the institutional capital capacity built by the country members indicates that the renegotiation process should incorporate the institutional capital already developed. The relevance of the decision of this scientific problem is that created institutional capital has critical effects on trade, marketing and environmentally sustainable development. Investigation of the topic in the paper is carried out in the following logical sequence based on literature review aimed to create a relationship between the analytical variables in order to obtain a research construct. Methodological tools of the research methods were reviewing 24 years of research on the implementation of NAFTA. The object of research is the chosen countries, of United States, Canada and Mexico, because namely they have created the NAFTA The paper presents the results of an empirical analysis of the implications in terms of cooperation and conflict relationships as institutional capital and their interactions with trade-marketing and environmentally sustainable development policy making which showed that the research model proposed and used to analyze is useful as a research construct. The research empirically confirms and theoretically proves that although the existence of NAFTA is severely questioned, its institutional capital has positive effects on the implications of trade-marketing, however, environmentally sustainable development proves to be conflictive and highly contentious, although some positive effects are developing. The results of the research can be useful for the renegotiations processes of individual firms, industries, economic sectors and countries under NAFTA.
\end{abstract}

Keywords: environment, institutional capital, marketing, NAFTA, trade, sustainable development.

JEL Classification: B52, D02, E02, F18, F13, F51, F53, F55, F64.

Cite as: Vargas-Hernández, J. G., Orozco-Quijano, E. P., Virchez, J. (2018). Critical Analysis On Institutional Capital On Trade And Environmentally Sustainable Development Under NAFTA. SocioEconomic Challenges, 4(2), 21-31. https://doi.org/10.21272/sec.4(2).21-31.2018.

(C) The Authors, 2018. This article is published with open access at Sumy State University.

\section{Introduction}

Sustainable development implies the implementation of natural, human, social and institutional capitals. The most tangible forms of capital are physical and natural. Physical capital refers to technical capital such as tools, equipment, etc. that work together with natural capital. Financial capital refers to stocks of money. Social capital is an interactional cooperative potential (Zenou, 2009) based on trust. Institutional capital is an asset related to the implementation of actions in development processes (Garrabé 2008). 
Institutions play a significant role in the sustainable development of nations (North, 1990). Institutions are defined as the formal and informal rules of the game, and transaction costs influence economic efficiency (North 1981, 1990; Williamson 1985; Eggertsson, Thrainn 1990). Institutional capital is related to institutional cost (Chen, 2008). The transformation of institutional capital into institutional costs creates mobility barriers in different organizational arrangements. Institutions have economic effects on sustainable development which are coined as institutional capital. Institutional capital is the limitations devised by man that shape human interaction, thereby structuring incentives in human exchange, be it political, social or economic (North, 1995: 13).

Economic institutions are a form of capital and, as such, are related to institutional capital in terms of the institutional structure of economic production, economic exchange relations and reducing transaction costs. Economic institutions are related to market institutions and are considered as instruments to reduce transaction costs. Institutional economic arrangements drawn by organizations are related to productive and exchange interactions.

The North American Free Trade Agreement (NAFTA) is an economic institution whose existence has been severely questioned by its members, although since its inception it has developed a type of institutional capital formed by relationships of cooperation and conflict. This institutional capital has serious implications in the interactions between free trade and its marketing activities with the environmentally sustainable capital.

Institutional capital has strong links with market institutions and therefore with marketing strategies and activities, for the creation and transaction of economic capital, financial, physical and natural resources, stocks and flows. Domestic markets generate institutional capital when they improve the dynamic capabilities to respond effectively to the demands of complicated external and internal business environments (Lan, 2011). The practical operation of institutional capital in strategic management and its relationship with competitive advantage is limited from the institutional and resource-based views. From the resource-based view theory, institutional capital is considered as non-material resources.

Thus, the recent renegotiations of the NAFTA that have led to the continuation in the United States, Mexico and Canada agreement (USMCA) has taken advantage of all the institutional capital already built.

The institutional capital approach is used in this study to analyze the relevance of North America Free trade Agreement (NAFTA) institutions in marketing activities and sustainable development. Institutional capital is the determinant for efficiency in marketing activities and sustainable development actions.

\section{Conceptualization of institutional capital}

The concept of institutional capital is relative and contingency-oriented in regards to the function of economic activities and the interactions between enterprises and institutions (Besharov and Smith, 2014). Institutional capital is a type of capital that refers to the economic value of rules, norms and cognition.

Institutional capital affects strategic organizational behavior and choices which translates into competitive advantages in terms of performance, value and ability (Zhang and Wang, 2010). Institutional capital is an intangible capital that can help to make better individual and organizational strategic decisions adapted to the interaction of internal and external environmental pressures to generate higher economic value (Martin, 2014) and better sustainable development. Institutional capital promotes value-creating activities. Institutional capital can nurture market and non-market capacities as a strategic environmental resource of the firm to enhance economic performance and dynamic responsiveness (Long, 2013).

For Hoff and Sen (2005), institutional capital is a mechanism that is shaped by shared values, norms, attitudes, expectations, standards and beliefs. Institutional capital is a concept related to the mainstream ideology and power identity to reflect the socio-cultural knowledge and skills about the institutional rules (Lin, 2005). Institutional capital is "the whole of the formal and abstract institutions which constitute the inciting structure organizing the relations between individuals or organizations, within the process of economic and social production” (Garrabé, 2007: 127).

Platje (2008: 145) defines institutional capital as the "institutions, institutional governance and governance structures that reduce uncertainty, stimulate adaptive efficiency (i.e. the ability of a system to adapt to changing conditions) and stimulates the functioning of the allocation system and sustainable production and consumption patterns" Institutional capital is understood by Vicencio Meza (2009) as the accumulation of formal or informal rules of the game and their compliance mechanisms, which have a positive or negative impact on economic performance. Institutional capital is the stock formed by the set of social rules and norms existing within a social nucleus, born of formal and informal structures, which define the entire structure of incentives 
or disincentives, determining the type of human behavior and integrating legal sanctions and morals. Institutional capital is an asset composed by formal and informal institutions that affect the adaptive efficiency of an economy's directly or indirectly productive activities (Ahrens and Jünemann, 2009).

Institutional capital is a unique and heterogeneous resource embedded in the external institutional environment that brings sustainable competitive advantage for enterprises (Lu, Zhou, Bruton and Li, 2010). Institutional capital, as a heterogeneous resource, is a unique, value-creating, scarce, inimitable and non-substitutable resource embedded within the organization's environment.

All these are the sources of institutional capital that can be translated into a sustainable competitive advantage. Institutional capital is an intangible asset that can facilitate the building of new institutions and the improvement of the ones that already exist, contributing to create and sustain societal and organizational competitive advantages.

\section{A. Components, elements, characteristics and properties of institutional capital}

At the micro level, institutional capital relates to corporate management and the competitive advantage of a firm by defining it as the resource, capacities and environmental factors embedded in the enterprise's institutional environment that can improve value-added assets and competitiveness. Thus, institutional capital is the input that can create economic income, from the perspective of corporate strategic management and acquisition of competitive advantage. At the micro level, institutional capital focuses on capital property and economic benefits (Traditions and history of the corporation constitute institutional capital imprinted in the business environment as an inimitable resource. More generally, institutional capital meets human needs efficiently and effectively as valuable productive assets (Shi and Ke, 2000).

At the macro level, institutional capital is related to the superiority in comparative institutional advantage of national economic and political institutions. The institutions of any state in any country that own institutional capital maximize the market and deepen the sustainable economic development. From the macro perspective, institutional capital is defined as the superiority resulting from national economic institutions and political institutions At the macro level, institutional capital can be the resources effectively controlled by the state or by improving strategies of civic and organizational forms of participation and civil society (Buell, 2005). Business groups can develop institutional capital with their own capabilities.

Institutional capital includes cognitive capital, normative capital and regulative capital (Scott, 1995). Cognitive institutional capital establishes mechanisms derived from the cognitive psychology to create a competitive advantage. The normative institutional capital establishes institutional mechanisms to adapt values and norms to economic rationality aimed to obtain a competitive advantage. Regulative institutional capital employs regulative mechanisms for formal and informal arrangements dividing institutional capital into formal and informal (Gao, et al. 2015). Formal institutional capital is formed by the formal acquisition of resources, while informal institutional capital is formed by resources, information and knowledge acquired through relational networks.

The institutional capital approach to sustainable development has the elements of public domain, institutional strength, good governance, and institutional equilibrium Institutional capital contributes to the legitimacy of the organization (Martinez and Dacin, 1999) through cultural-cognitive consistency (Yang and Su, 2014). The institutional capital is an element of the environment or institutional framework, including organizational and familial institutions, morals, deontology, rules, etc., and other institutional resources with any direct relation to economic production, interactions and exchanges.

The institutional capital is analyzed by Loureau (1972) in three phases: the pre-established institutions becoming unconscious habitus (Bourdieu, 1972) or habit (Hodgson, 2006). With time, the appearance of social strains and crisis leads to social change with an institutionalization process that may reach a period of stabilization. The accumulation of institutional capital is in slow evolution in time, except during periods of crisis and is done incrementally by successive contributions (North, 1991). However, accelerated institutional capital accumulation can turn into a contradictory institutional arrangement without operational links. Also, the disinstitutionalization processes may result in accumulation or dis-accumulation of institutional capital (Hodgson, 2006), which can be an individual or institutional convergence, voluntary, negotiated or imposed.

The measuring methods of institutional capital are based on operationalization conducted by external institutions, such as government, and on institutional characterization within the organization. 
Institutional capital, although a relatively recent created subject, has been already developed a theoretical and methodological frame of reference, components, elements, characteristics and properties, which are a departure to continue the study and the analysis of this topic.

\section{B. Institutional capital and sustainable development}

Institutional capital is a fundamental requirement of sustainable development. Nations benefit from institutional capital stocks (Trebilcock, 1996; Kaji, 1998 and Ahsan, 2003). Institutional capital is an essential component of sustainable development. Institutional capital with good quality institutions adapted to contribute to sustainable development can be generated through institutional reform. Institutional capital influences the development of political and economic sustainable development of modern society (Brunell, 2005). The existence of institutional capital is essential for any type of sustainable development with an efficient productive, exchange and consuming system.

Institutional capital can achieve sustainable development through four sources: public domains, economic systems, governance structures, and formal-informal institutions (Platje, 2008). Public domain favors opportunistic and rent-seeking behaviors, which decreases institutional capital and increases transaction costs due to lack of explicit property rights. The economic system provides incentives for economic activities. Governance is related to rule and policy development. The equilibrium of institutional informality and formality balance the institutional capital.

The quantity and quality of institutional capital stock and flows play a determining role in economic sustainable development and the reduction of poverty. Good quality institutional capital and fair trade lead to a decrease in inequality (Mamoon, 2007; 21). Institutional capital capacity is a condition to sustainable development policy achievements (Evans et al., 2006). Institutional changes and reforms requiring the use of other forms of capital may accelerate the accumulation of institutional capital required for the improvement of sustainable development and poverty reduction.

Thus, sustainable development is related to institutional capital in a sense that can be considered and intangible and valuable asset for organizational and societal development.

\section{Relationships of cooperation on the interaction between trade and environmentally sustainable de- velopment}

International organizations relating and promoting open trade around the world are concerned with relationships of cooperation and conflict between marketing and sustainable development. There is a need for international coordination for relationships of cooperation and conflict aimed at open trade and free market to achieve sustainable economic development. The World Summit on Sustainable Development in 2002 called for more cooperation among the United Nations Economic Program (UNEP), the Bretton Woods institutions, and the World Trade Organization (WTO) (UN, 2002).

Under the framework of the North American Free Trade Agreement (NAFTA), The Commission on Environmental Cooperation was established in 1992 as the dispute settlement body of the Commission for Environmental Cooperation (CEC) to deal with issues of harmonization of environmental standards and restrictions to the exploitation of resources. The North American Agreement on Environmental Cooperation (NAAEC) attempted to bring environmental issues into the open trade discourse, by merging the international environmental frameworks into the framework of a free trade agreement, although it does little to raise environmental standards (NAAEC, 1993).

The adjudicatory perspective has also initiated the multilateral convergence for cooperation on trade, environmental and sustainable development concerns. This objective became clear in the North American Agreement on Environmental Cooperation (NAAEC) as a side-treaty of the North American Free Trade Agreement (NAFTA), which is considered the cornerstone in the integration of environmental rules and provisions. Other later attempts made by the Organization for Economic Cooperation and Development were unsuccessful due to irreconcilable interests between the member states.

It is quite important for international negotiators to take into account the common inter-state contexts of historical and cultural values when advancing market proposals aimed at economic sustainable development. Free trade agreements between neighboring countries are prone to have politically focused agreements to set a stage for greater coordination and cooperation relationships between relevant actors to ensure market and environmental activities. These agreements integrate broad norms and regulations to facilitate the interactions and exchanges of information supported by principles of responsibility. However, under the frame of NAFTA, the 
United States of America has adopted a more confrontational approach instead of a cooperative approach for monitoring compliance of environmental and sustainable development regulations by focusing on local capacity building without technical assistance that is leading to severe disputes and conflicts.

More cooperation in international economic and technical assistance is required, assuming there are resources available on the basis of underlying principles of constitutional pluralism and international justice aimed at the impact of trade on sustainable development issues.

Thus, the analysis of relationships of cooperation on the interaction between trade and environmentally sustainable development is relevant to understand the implications in terms of incentives, transactions costs, etc., involved in the creation and improvement of institutional capital.

\section{Conflicts between trade and environmentally sustainable development}

Organizational and institutional isomorphism does not necessarily mean equifinality as an import of highly idealized global culture into diverse local contexts; domestic conditions seem to be infeasible and lead to conflictive components. These local resistances to global culture may be the result of the state's commitment to preserve identity and socioeconomic development (Finnemore \& Sikkink, Meyer \& Rowan, 1977; Strang \& Meyer, 1993).

Although some conflicts and disputes in NAFTA have dealt with environmental and trade concerns more than on investment and trade, a good example is the conflict of public rights of action between Mexico and the United States that emerged with the sugar disputes and collided with private rights of action. Also, one of the other most relevant conflicts has been the movement of Mexican small farmers, including El Barzon, who were producing crops in disadvantaged and non-competitive conditions under the NAFTA frame. They protested in January 2003, seeking better positions in the trade agreement of maize and beans and the renegotiation of the agricultural chapter.

Agricultural trade policies in Mexico under the framework of the renegotiation of NAFTA's agricultural chapter have been modified in response to organizations of small-scale farmer's mobilizations and international commitments. However, the claim of renegotiation was not achieved to be incorporated in the agro pact and agricultural production was constrained to quotas. This conflict was solved by the Mexican government maintaining a position in equilibrium between domestic demands and constraints and international imperatives.

The formation of trade commission's raises serious problems for cooperation relationships and may lead to conflicts in terms of their functions, accountability, transparency, judicial roles, arbitration proceedings and inconsistency in decisions in the complexity of economic globalization processes. In cross-border jurisdictional conflicts, national courts and legislatures may protect legitimate interests of transnational jurisdictions and governance and protect the principles of cosmopolitan justice. However, the cosmopolitan international economic law, transnational integration law and adjudication perspective refute the incapability of law to provide justifications for normative solutions by institutionalizing public reason to limit power politics.

Adjudicatory conflicts may lead to the creation of environmental regimes and mechanisms for negotiation and regulations which may transform the state into a manager of regulatory norms. To avoid conflicts on the enforcement of national regulations on trade and environmentally sustainable development between different countries, the best solution is to enforce the application of international standards and regulations. However, some member states may enforce more strict regulations than those approved by international standards and regulations, which in turn lead to conflicts. Options to resolve this type of conflicts should be investigated.

The different processes used to reduce the tensions and solve the conflicts and disputes inherent to trade and environmentally sustainable development should be investigated, however, it is more appropriate to try to find solutions at earlier stages before the conflict and dispute arises. Conflicts between the parties should be resolved through mutually consistent interpretations and cross border judicial protection of the rule of law. Legal and administrative principles and regulations are necessary to protect individual human rights, the role of the economic market and trade and environmentally sustainable development from conflicts between private and public interests and between national and inter-state interests.

Thus, institutional capital is critical for the resolution of emerging conflicts under the framework of the new agreement, already called USMCA (Unites States Mexico Canada). In fact, Canadians have negotiated this issue facing the US position of submission to the United States institutions. 


\section{Research model for critical analysis}

In order to review and realistically analyze literature related to our research topic, it is necessary to display the main variables, their relationships and interactions in the operating framework of the North American Free Trade Agreement (NAFTA). As an independent variable, institutional capital is considered in two dimensions: relationships of cooperation and conflict. The dependent variable is considered the environmentally sustainable development policy making and the mediating variable is trade and marketing activities. Figure 1 shows the relationships between the three variables.

The research model proposed here for the analysis of trade and marketing activities using the framework of the North American Free Trade Agreement (NAFTA) is based on the study of relationships of cooperation and conflict as critical components of institutional capital. These variables have a relevant impact on environmental sustainable development policy making.

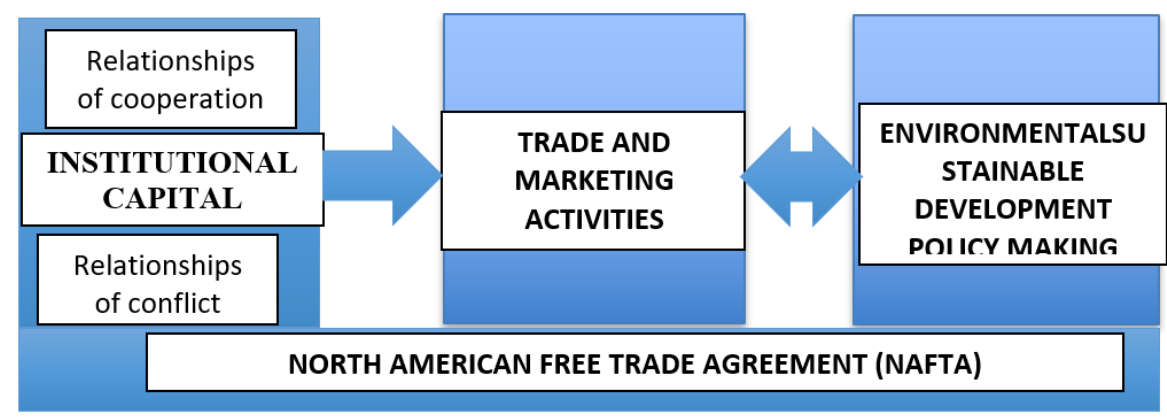

Figure 1. Research model for the analysis of institutional capital on trade-marketing and environmentally sustainable development policy making

\section{Trade-marketing and sustainable development: A dialogical relationship of cooperation and conflict}

The incremental improvement and radical or disruptive changes of industrial innovation involves the commercialization and marketing of technological change, including small-scale changes in technological know-how “disruptive”' innovation (Rothwell and Zegveld, 1985). The relationships and interactions between the countries in the field of trade expand to the production and marketing of goods and services allowing for the optimal use of natural resources in accordance with the aims of sustainable development, seeking to protect and preserve the environment consistent with the needs and concerns of current and future generations.

Free trade regimes have a limited role in the normative approach to environmental sustainability (Trujillo, 2013). NAFTA has focused on the enforcement of national regulations while the European Union relies more on policy coherence and cooperation between the trade partners. NAFTA institutions influence trade and environmental sustainability policies by taking into consideration that country members defer their authority based on expertise, social network and institutional memory (Jinnah, 2010). NAFTA institutions influence trade and environmental sustainability politics by legitimizing the strategic marketing practices and technical knowledge brokerage and attempting to level the development between countries (Jinnah, 2010).

The marketing approach to the interaction between trade and environmentally sustainable development is subject to the expertise and social networks involved (Jinnah, 2010). Marketing organizational rules and norms in NAFTA to frame, design and shape access to memberships of NGOs is an important activity to spread understanding of the implications between trade and environmental sustainability (Jinnah, 2010).

The guidelines approach of minimum standards for health, safety and hazardous products regulate and establish international rules for marketing control (Micklitz, 2000). NAFTA regulations on the local production of drugs, promotion of traditional medicines, personal training, and compliance of manufacturers' marketing and promotional efforts with public health objectives were considered irrelevant (Harland, 1987: 257-258; Merciai, 1986: 217). NAFTA should market regulations, norms, and practices on the health benefits of products through direct participation in cross border exhibitions, fairs, expositions and other events.

One good example of the use of marketing techniques in trade under the framework of NAFTA and its implications on environmentally sustainable development is the analysis conducted by Rodriguez Diaz (2012) of the Canadian and Mexican dairy producer corporations. Agropur is a dairy producer cooperative company from Quebec with more than 4 cooperative members in 21 plants in Canada and the United States (Industry Canada, Agropur's Profile, 2005).

Processing and manufacturing of primary agricultural products in marketing theory are perceived as product 
differentiation in marketing and trade (Harris, 1984; Hertel, 1994). Food processing sectors are characterized as oligopolistic in the North American market combining the strategies of product differentiation, endogenous price mark-ups and freedom of exit-entry (Harrison, et al., 1995). Both Canadian and Mexican dairy transnational companies do not use direct marketing techniques influenced by the environment to foster regional and local dairy market developments to be competitive. Agropur is influenced by the competence of Kraft and Saputo while Lala is influenced by Danone and Nestlé in order to remain competitive.

The international marketing regulations on product safety aimed to establish control of hazardous products to protect consumers against production and marketing have not been undertaken. Marketing regulations and rules in NAFTA must be robust to involve commodities distinct in production and marketing arrangements and practices on trade and their relationship with environmentally sustainable development. Since the early 1990s, the inter connection between trade and environmentally sustainable development policies have been debated prominently during the negotiations and after that the renegotiations about the North American Free Trade Agreement (NAFTA).

Environmental organizations and groups harshly criticize the marketing approach to trade and environmental sustainability concerns, claiming that more transparency and accountability is needed by facilitating open access to the public information through digital, conferences and printed outlets. A process of transparency and accountability that makes information accessible to all the economic agents and to the public, and is promoted by institutions of NAFTA increases the institutional capital. Other actions to increase transparency are to market rules, norms, practices, activities, etc., through direct participation of economic agents and the general public in events.

NAFTA must continue working in marketing organizational regulations, rules and norms related to the interaction between trade and environmental sustainability opening to critical access to frame and shape policies to broader public understanding (Weiler, 2001, 14-15. 66; Hudec, 1999). The role of the NAFTA member countries in marketing the regulations, rules and norms to other organizations, as well as the negotiations and brokerage are critical activities to develop and maintain legitimacy through the design, shaping and sharing of the relationships and interactions between trade and environmental policy developments.

Unfortunately, there is a lack of clarity and explicit provisions to regulate the side effects of interactions between marketing regulations in trade and environmentally sustainable development. However, international organizations engaged in developing global marketing strategies have developed eco-label regulatory schemes to identify the product's impact on the environment based on the life cycle and provide information to consumers about the environmental quality.

Thus Trade and marketing are both critical for exchange activities of products and services which in turn are relevant for the economic growth, social development and environmental sustainability of the countries that are members of the new brand United States, México and Canada agreement.

The free trade agreements have a normative role in environmental sustainability. The approach of NAFTA to trade-environment is more normative than practical and overlaps management interaction with environmentally sustainable development issues internally, informally and quite limited. The Mexican government implemented NAFTA to stimulate sustainable development. The Mexican sustainable development is a guideline of the operation of free trade agreements aimed at the optimal use of natural resources and seeks to protect and preserve the environment. NAFTA is slowly shaping the relationship trade-environment politics, which is becoming increasingly relevant and contributes to organizational legitimacy by setting the regulations, norms and processes.

The administrative and judiciary functions of NAFTA grapple with trade jurisprudence to better accommodate domestic policies to address sustainable development and to develop green economy policies and strategies. Administrative and adjudicatory functions of free trade agreements should grapple with trade jurisprudence that may better accommodate for domestic policies intended to address sustainable development concerns, other international organizations are engaging in developing global strategies for sustainable development.

The principle of sustainable development is incorporated in the free trade agreements in order to achieve a balance between economic and non-economic rights and concerns of current and future generations. Furthermore, it has become relevant to analyze social issues and implement policies that may intersect with trade and sustainable development, protection and preservation of natural resources and to address climate change 
concerns. Also, the linkages between trade principles, economic growth, sustainable consumption, social issues, climate change concerns and environmentally sustainable development must need to be promoted and raise awareness by policy-makers at domestic and regional levels.

The dialogic approach provides a nonhierarchical framework for the analysis of interactions between trade and environmental sustainability issues. Trujillo (2013) uses a dialogical approach to frame trade governance and to explain the adjudicatory and administrative functions in cross-fertilization between trade and environmental sustainability issues towards a convergence between domestic and global environmental and trade regulations. International organizations may support convergence with the States through different forms of cooperation in the development and implementation of trade and environmentally sustainable development regulations. The manner in which trade regimes deal with environmental policies influences the link of economic development with sustainable development.

NAFTA was the first free trade agreement to incorporate trade concerns into environmental sustainability issues through the formalization of NAAEC. NAAEC has an adjudicatory mechanism to claim environmental sustainability disputes although it is not being used at all. NAFTA involves complex exchange relationships of trade and environmental sustainability issues between the three countries which involve cross-border supply chains and technological changes. This mechanism has been useful in cross-fertilization processes of environmental and trade concerns. This process of cross fertilization between trade and environmental sustainability issues within the NAFTA trade jurisdiction has an impact on the convergence of national regimes.

The relationships between advocating foreign investment, trade and sustainable development should be emphasized and balanced with the pursuits of economic growth objectives through environmentally sustainable growth. Free trade agreements may directly impose foreign investment national regulations upon sustainable development. Furthermore, policymaking includes foreign investment and international governance for sustainable development and integration of investment policies. NAFTA's Environmental Side Agreement began to direct attention to the relevance of an agenda for foreign investment and sustainable development. The best endeavor clause does not impose proper substantive obligations upon contracting parties but the right to adopt, maintain and enforce measures considered appropriate to ensure sensitive investments to environmentally sustainable development concerns. Besides, the parties may consult each other.

NAFTA should contribute to the sustainable development of the countries. Foreign investment policy for sustainable development should be aligned with investment for inclusive economic growth, social issues and environmental concerns. Foreign investment policies in host countries must be aligned and integrated with its sustainable development strategy. Protection of foreign investment should not hinder the power of the host state to regulate public interests for public health, safety, social issues and environmentally sustainable development concerns. Passive action of host states reduces the operation costs of foreign investments and cannot claim rights.

Complex economic, social and political changes initiated during the 1980s in Mexico had an impact on the economic organization and social structure of rural development and rural livelihoods. Despite the fact that rural communities were strained, corn persists as the main crop of livelihood strategy (de Janvry, Sadoulet, and de Anda, 1995; Eakin et al., 2014; Wiggins et al., 2002). Regional cross-border integration in agriculture under the trade framework of NAFTA is provided by the cross-border cattle trade. The disruption of the process of integration of the red meats industry occurred across borders (Veeman, 2017).

This situation has created some concerns for Mexicans regarding food security and food sovereignty. Food security is considered the permanent supply of 'basic and strategic staples' for the population and 'food sovereignty' is the priority accorded to national production for supplying the staples, according to the Mexican Law of Rural Sustainable Development (December, 2001) (Cámara de Diputados, 2003: 96). The environmentally sustainable development policy and strategy may be implemented by voluntary schemes through business, non-governmental organizations and local communities to improve performance.

Environmental sustainable development is being considered in the renegotiated NAFTA, now under the acronymic Unites States, Mexico and Canada, as an important and critical issue for the development of commercial exchanges. In fact, the new agreement proves the importance that the institutional capital already created and developed has been essential for the renegotiations of the new agreement.

\section{Conclusions}

The critical analysis of the implications that the relationships of cooperation and conflict have in building the institutional capital capacity as developed through the existence of the North American Free Trade Agreement, 
which is severely questioned by its country members, reveals that it has positive effects on trade and marketing activities. However, the interaction of the relationship between trade-marketing activities with environmentally sustainable development proves to be highly contentious and conflictive, although some developments are proving to be positive.

A strategic future definition of NAFTA requires more structural flexibility, not only in regards to regulations, but also in developing capabilities by considering the specific environments of each involved country. The combination of capabilities and regulations are necessary to develop new forms of association, such as the horizontal alliances.

Institutional capital development in NAFTA may increase the opportunities to improve the relationships of cooperation, the exchange and interaction between the three nations and among the main economic agents in specific areas of market development, trade operations and environmentally sustainable development. Lowering transaction costs of the trade operations and enforcing sanitary and phytosanitary concerns are only two issues to take care of.

\section{References}

1. Ahrens, J. and Jünemann, P. (2009). Adaptive efficiency and pragmatic flexibility: characteristics of institutional change in capitalism, Chinese-style. Unpublished Paper [online], available at http://www.centralasiaproject.de/index.php?option=com_docman\&task=doc_download\&gid=32\&\&Itemid=7.

2. Ahsan, S. M. (2003). Institutional Capital and Poverty: A Transition Economy Perspective, in A. Shorrocks and R. van der Hoeven, Eds. Perspectives on poverty and growth. United nations University Press.

3. Ashby, C. \& Carney, D. (1999). Sustainable livelihoods: lessons from early experience. London, UK, Department for International Development. Cited by Warner, 2000.

4. Besharov, M.L. and Smith, W.K. (2014) Multiple Institutional Logics in Organizations: Explaining Their Varied Na- ture and Implications. Academy of Management Review, 39, 364-381. http://dx.doi.org/10.5465/amr.2011.0431

5. Bossier, S. (2003). Desarrollo territorial y descentralización. Lima.

6. Bourdieu, P. (1972), Esquisse d'une théorie de la pratique. Genève: Droz, (new edition in Paris: Seuil, coll. Points Essais, 2000, 429 pages).

7. Bruell, L. (2005). Institutional Capital: Building Post-Communist Government Performance. University Press of America, Lanham.

8. Brunell, L. (2005). Institutional Capital: Building Post-Communist Government Performance. University Press of America.

9. Cámara de Diputados (2003). Compilación de leyes para el campo, México, El campo no aguanta más (2002), 'Seis propuestas para la salvación y revaloriza- ción del campo mexicano’, mimeo (12 organizations signing), November.

10. Chen, Z.W. (2008). Why Hard-Working Chinese People Are Not Wealthy. CITIC Press, Beijing.

11. de Janvry, A., Sadoulet, E., and de Anda, G. G. (1995). NAFTA and Mexico's maize producers. World Development 23:1349-62. Johnson, D. G. (1975). World agriculture, commodity policy, and price variability.

12. Eakin, H., Perales, H., Appendini, K., and Sweeney, S. (2014). Selling maize in Mexico: The persistence of peasant farming in an era of global markets. Development and Change, 45, 133-155.

13. Eggertsson, Thrainn. (1990). Economic Behavior and Institutions. Cambridge, Cambridge University.

14. Evans, B. et al. (2006), Governing local sustainability, Journal of Environmental Planning and Management, 49(6), 849-867.

15. Finnemore, M. \& Sikkink, K. (2007). International Norm Dynamics and Political Change, 52 INT'L ORG.

16. Gao, Y., Gao, S. and Zhou, Y. (2015). Picturing Firms’ Institutional Capital-Based Radical Innovation under China's Institutional Voids. Journal of Business Research, 68, 1166-1175. http://dx.doi.org/10.1016/j.jbusres.2014.11.011

17. Garrabé, M. (2008). Note sur l'existence du capital institutionnel, Unpublished Paper, Workshop University of Montpellier 1 and Sherbrook University, June, 23-24, 2008, 24 p. http://www.michel-garrabe.com.

18. Garrabé, M. (2007). Economie sociale et développement, Programme MED-TEMPUS, 220 pages, http://www.formder.iamm.fr.

19. Harland, D. (1987). Some international dimensions of consumer policy and law. Journal of the Indian Law Institute, 29, 451-467.

20. Harris, R.G. (1984). AppUed General Equilibrium Analysis of Small Open Economies with Scale 
Economies and Imperfect Competition. American Economic Review, 74, 1016-1032.

21. Harrison, G. W. Rutherford, T. F. and Tarr, D. G. (1995). Quantifying the Uruguay Round. In Martin, W. and Winters, L. A. (eds). The Uruguay Round and Developing Economies, World Bank discussion paper, 307.

22. Hertel, T. W. (1994). The Procompetitive Effects of Trade Policy Reform in a Small Open Economy. Journal of International Economics, 36, 391-411.

23. Hodgson, G. M. (2006). What are institutions? Journal of Economic Issues. 40(1), 1-25.

24. Hoff, K. and Sen, A. (2005). The Kin System as a Poverty Trap? World Bank Policy Research Working Paper, 3575.

25. Hudec, R. (1999). New WTO Dispute Settlement Procedure: An Overview of the First Three Years. Minnesota Journal of Global Trade, 8(1), 1-53.

26. Industry Canada, Agropur's Profile (2005). Canadian company capabilities [online]. http://strategis.ic.gc.ca/app/ccc/search/navigate.do?language=eng\&portal=1\&estblmntNo=131336240000\&profile $=$ complete Profile.

27. Jinnah, S. (2010). Overlap Management in the World Trade Organization: Secretariat Inouence on TradeEnvironment Politics. Global Environmental Politics, 10(2).

28. Kaji, G. S. (1998). Institutions in Development: the Country, Research, and Operational Challenges. In Picciotto, R. and Weisner, E. (eds.) Evaluation and Development: The Institutional Dimension. World Bank, Washington, D.C., pp. 3-6.

29. Klabbers, J. (2013). Unity, Diversity, Accountability: The Ambivalent Concept of International Organisation, Melbourne Journal of International Law, 149, p. 152.

30. Lan, H.L. and Pi, S.L. (2011). On Strategic Choices of Chinese Corporation under Dual-Condition of Economic Globalization and Market Fragmentation. Journal of Management, 8, 1107-1114.

31. Lin, N. (2005). Social Capital: A Theory of Social Structure and Action. Century Press, Shanghai.

32. Long, Y.A. (2013). An Empirical Study of the Effect of Non-Market Factors on China's Overseas Direct Investment. International Economics and Trade Research, 7(8).

33. Loureau, R. (1972). L'Analyse Institutionnelle. Paris, Les Editions de Minuit, (Arguments), 298 pages.

34. Lu, Y., Zhou, L., Bruton, G. and Li, W. (2010). Capabilities as a Mediator Linking Resources and the International Performance of Entrepreneurial Firms in an Emerging Economy. Journal of International Business Studies, 41, 419-436. http://dx.doi.org/10.1057/jibs.2009.73.

35. Mamoon, D. (2007). Good Institutions and Fair Trade: A Road Map to Local and Global Social Harmony, Working Paper No. 450, Institute of Social Studies, The Netherlands.

36. Martin, X. (2014). Institutional Advantage. Global Strategy Journal, 4, 55-69. http://dx.doi.org/10.1111/j.2042-5805.2013.01072.x.

37. Martinez, R.J. and Dacin, M.T. (1999). Efficiency Motives and Normative Forces: Combining Transactions Costs and Institutional Logic. Journal of Management, 25, 75-96. http://dx.doi.org/10.1177/014920639902500104.

38. Merciai, P. (1986). Consumer protection and the United Nations. Journal of World Trade Law, 20, 206-231.

39. Meyer, J.W. and Rowan, B. (1977) Institutionalized Organizations: Formal Structure as Myth and Ceremony. American Journal of Sociology, 83, 340-363. http://dx.doi.org/10.1086/226550.

40. Micklitz, H. W. (2000). International Regulation on Health, Safety, and the Environment - Trends and Challenges. Journal of Consumer Policy, 23, 3-24.

41. NAAEC (1993). North American Agreement on Environmental Cooperation, Sept. 14, 1993, 32 I.L.M. 1480, reprinted in The Nafta Supplemental Agreements (United States Government Printing Office ed., 1993) [hereinafter NAAEC].

42. North, D. (1995). Instituciones, cambio institucional y desempeño económico. México, Fondo de Cultura Económica.

43. North, D. (1995). Institutions, institutional change and economic performance. Cambridge: Cambridge University Press.

44. North, D. (1991). Institutions, Journal of Economic Perspectives, 5(1), 97-112.

45. North, D. (1990). Institutions, Institutional Change and Economic Performance, Cambridge University Press, 159 pages.

46. North, D. C. (1981). Structure and Change in Economic History. New York and London, W.W. Norton.

47. Platje, J. (2008a). Institutional capital as a factor of sustainable development - the importance of an institutional equilibrium, Technological and Economic Development of Economy, 14(2), 144-150. http://dx.doi.org/10.3846/1392-8619.2008.14.144-150.

48. Rodriguez Diaz, A. J. (2012). Transferring knowledge in Quebec-Mexico partnerships: the case of the dairy industry. J. Technol. Transf., 37, 631-647. DOI 10.1007/s10961-010-9197-0 
49. Rothwell, R., \& Zegveld, W. (1985). The process of technological innovation: Patterns and influences. In Reindustrialization and technology (Chap. 2, pp. 47-82). Harlow, England: M.E. Sharpe Inc. 282.

50. Scott, W.R. (1995). Institutions and Organizations. SAGE Publications, Thousand Oaks.

51. Shi, M.F. and Ke, W.G. (2000). Institutional Economics. Commercial Press, Beijing.

52. Strang, D. \& Meyer (1993). Institutional Conditions for Diffusion, Theory and Sociology, 22(4), 87.

53. Trebilcock, M. (1996). What Makes Poor Countries Poor? The Role of Institutional Capital in Economic Development, Berkeley Olin Program in Law \& Economics, Working Paper Series, http://ideas.repec.org/p/cdl/oplwec/1149.html.

54. Trujillo, E. (2013). A dialogical approach to trade and environment. Journal of International Economic Law, 16(3), 535-585. doi:10.1093/jiel/jg;t019.

55. Vicencio Meza, J. A. (2009). Capital Institucional y Desarrollo Económico: Una aproximación a la relación normativa-conductual en comunidades extranjeras. Empresarios Judíos en Chile. 1930-1970. Seminario de Grado Licenciado en Historia "Reglas, capacidades y redes en el desempeño económico De familias judías en Chile: 1930-2009” Universidad de Chile Facultad de Filosofía y Humanidades Departamento de Ciencias Históricas.

56. UN (2002). UN Report of the World Summit on Sustainable Development, Johannesburg, South Africa, Aug. 2002, available at http://www.unmillenniumproject.org/documents/131302_wssd_report_reissued.pdf.

57. Veeman, M. (2017). Keynote address. North American Trade Policy for Agriculture and Forestry: Can Economics Trump Politics? Canadian Journal of Agricultural Economics, 65, 43-68. DOI: 10.1111/cjag.12135.

58. Weiler, J. (2001). The Role of Lawyers and the Ethos of Diplomats: Reoections on the International and External Legitimacy of WTO Dispute Settlement. Journal of World Trade, 35(2), 191-207.

59. Wiggins, S., Keilbach, N., Preibisch, K., Proctor, S., Herrejón, G. R., and Muñoz, G. R. (2002). Discussion - Agricultural policy reform and rural livelihoods in central Mexico. Journal of Development Studies, 38, 179-202.

60. Williamson, O. E. (1985). The Economic Institutions of Capitalism. New York, Free Press.

61. Yang, Z. and Su, C. (2014). Institutional Theory in Business Marketing: A Conceptual Framework and Future Directions. Industrial Marketing Management, 43, 721-725. http://dx.doi.org/10.1016/j.indmarman.2014.04.001.

62. Yang, F. and Wang, H.S. (1997). Social Research Methods. Peking University Press, Beijing.

63. Zhang, J.W. and Wang, Y.J. (2010). Evaluation and Future Prospects for Competitive Advantage and Evolution. Foreign Economics and Management, 3, 1-10.

64. Zenou, Y. (2009). Urban Labor Economics, Cambridge: Cambridge University Press. 